\title{
On the identity and distribution of the poorly known spider Orthobula charitonovi (Mikhailov, 1986) (Aranei: Corinnidae)
}

\section{Об определении и распространении малоизвестного вида пауков Ortbobula charitonovi (Mikhailov, 1986) (Aranei: Corinnidae)}

\author{
Yuri M. Marusik ${ }^{1,2}$, Recep Sulhi Özkütülk ${ }^{3}$ Kadir Boğaç Kunt ${ }^{4}$ \\ Ю.М. Марусик ${ }^{1,2}$, Р.С. Ёзкютюк ${ }^{3}$, К.Б. Кунт ${ }^{4}$
}

\footnotetext{
${ }^{1}$ Institute for Biological Problems of the North RAS, Portovaya Str. 18, Magadan, Russia. E-mail: yurmar@mail.ru.

${ }^{2}$ Zoological Museum, University of Turku, FI-20014 Turku, Finland.

${ }^{3}$ Anadolu University, Faculty of Science, Department of Biology, TR-26470 Eskişehir, Turkey E-mail: sozkutuk@gmail.com

${ }^{4}$ Poligon Site, 71/27B, TR-06810 Türkkonut, Ankara, Turkey E-mail: chaetopelma@gmail.com

${ }^{1}$ Институт биологических проблем Севера ДВО РАН, Портовая 18, Магадан 685000, Россия.
}

KEY WORDS: Middle East, Central Asia, Caucasus, Israel, Iran, sac spiders, new record, redescriptions.

КЛЮЧЕВЫЕ СЛОВА: Средний Восток, Центральная Азия, Турция, Кавказ, Израиль, пауки мешкопряды, новая находка, переописание.

ABSTRACT. New data on the distribution and morphology of a poorly known corinnid spider Orthobula charitonovi (Mikhailov, 1986) is given. It is recorded from Israel, Iran and Uzbekistan for the first time. The habitus, pattern and copulatory organs from different populations are illustrated in detail. Occurrence of spine locking mechanism in spiders briefly discussed.

РЕЗЮМЕ. Приведены новые данные по распространению и морфологии Orthobula charitonovi (Mikhailov, 1986). Вид впервые отмечается для территории Израиля, Ирана и Узбекистана. Даны иллюстрации габитуса, окраски и копулятивных органов из разных попу-ляций. Кратко обсуждается распространённость замкового механизма для шипов ног среди разных групп пауков.

\section{Introduction}

Orthobula Simon, 1897 is a relatively small genus (17 species) of corinnid spiders distributed in Africa and the Eastern Mediterranean to Taiwan. It was placed in Liocranidae for a long time and was transferred to Corinnidae by Bosselaers \& Jocqué, [2002]. Only two species of the genus are known in the Palaearctic: $O$. charitonovi (Mikhailov, 1986) and O. crucifera Bösenberg et Strand, 1906. Both are known exclusively from Asia. Three species from Tibet described in Orthobula (O. qinghaiensis $\mathrm{Hu}, 2001, O$. tibenensis $\mathrm{Hu}, 2001$ and O. zhangmuensis $\mathrm{Hu}$ et $\mathrm{Li}, 1987$ ) are misplaced [Platnick, 2013; personal observation of Y.M]. Orthobula yaginumai Platnick, 1977 from China occurs outside the Palaearctic part of the country.

Both species occurring in the Palaearctic have nearly the same northern distribution limit of about $40^{\circ} \mathrm{N}$. Orthobula crucifera is known from Ryukyu to Honshu in Japan [Kamura, 2009] and O. charitonovi penetrates to northern Georgia and Kyrgyzstan (ca. $42^{\circ} \mathrm{N}$ [Mikhailov, 1986; Otto \& Tramp, 2011]).

The latter species was reported from Armenia, Azerbaijan, Georgia, Turkmenistan and Kyrgyzstan [Mikhailov, 1997]. Recently, O. charitonovi was found in Turkey [Danışman et al., 2012]. While studying spiders from Iran, Turkey, Georgia, Uzbekistan and Israel we found several dozens of specimens at more than twelve localities. The aims of this paper are to redescribe this poorly known species and to provide new data about its distribution.

\section{Material and Methods}

The specimens were collected at different localities either by sifting leaf litter or hand picking and preserved in $70-80 \%$ ethanol (Map 1). Digital images of the pedipalp and vulva were taken with an Olympus Camedia E520 camera attached to an Olympus SZX16 stereomicroscope. Ten to thirty photographs were taken in different focal planes and combined using "CombineZP" image stacking software. Photographic images were edited by using PHOTOSHOP CS2 and COREL-DRAW X3 was used to create the plates. For SEM micrographs, the male palps were dried at $30^{\circ} \mathrm{C}$ and coated with a thin layer of gold using an Electron Microscopy sciences EMS 550X sputter coater. The materials were examined at an acceleration voltage of $12 \mathrm{kV}$ using a ZEISS ULTRA PLUS Scanning Electron Microscope (Located at the University of Anadolu, Eskişehir, Turkey), and the electron micrographs were recorded. The material treated here is deposited in the Zoology Museum of Anadolu University (AUZM) and the Zoological Museum of the Moscow State University (ZMMU).

All measurements given within text are in millimetres and abbreviations and their explanations are as 


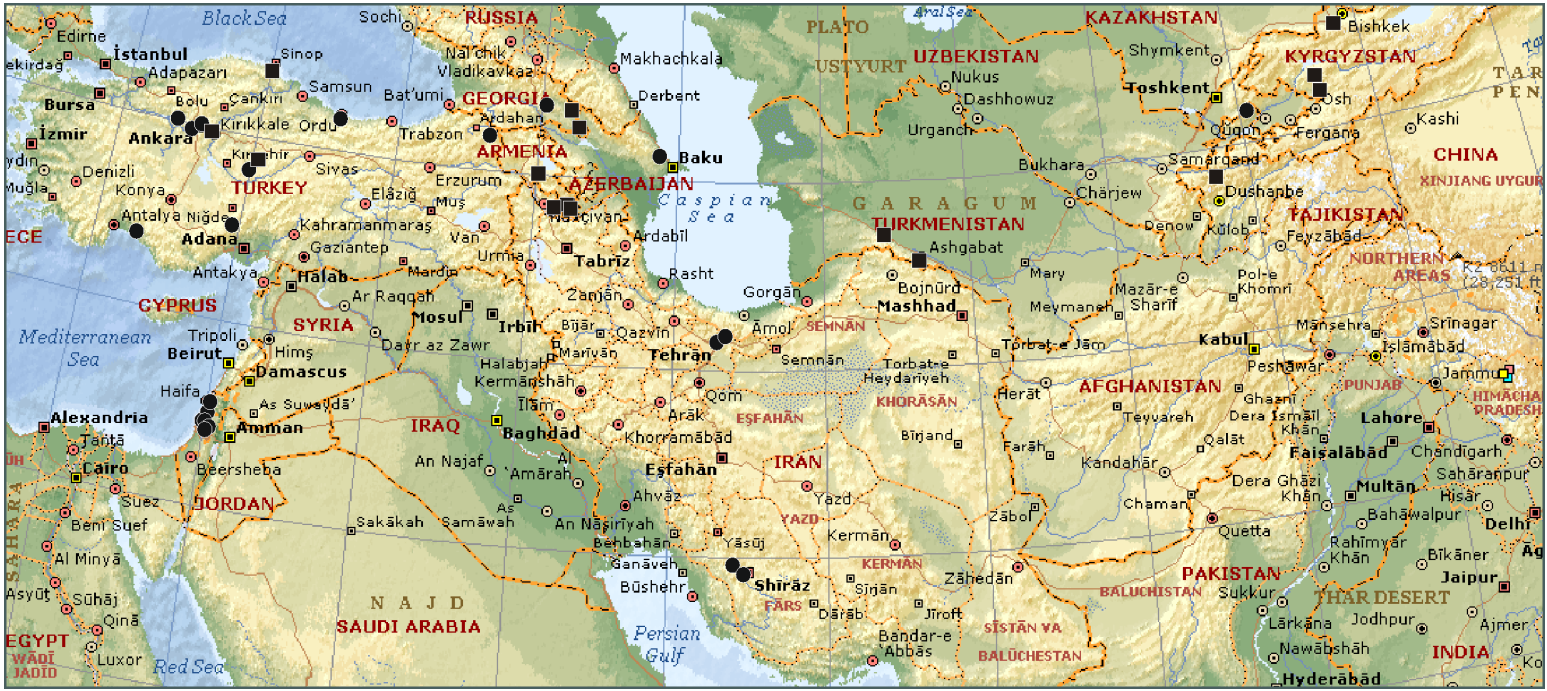

Map 1. Distribution of Orthobula charitonovi (circles - our data, squares - literature data).

Карта 1. Распространение Orthobula charitonovi (кружки - наши данные, квадраты — литературные данные).

follows: $\mathrm{AL}$ - abdominal length; $\mathrm{CL}$ - carapace length; Cwmax - maximum carapace width; Cwmin minimum carapace width in cephalic part; ALE anterior lateral eyes; AME - anterior median eyes; PLE - posterior lateral eyes; PME — posterior median eyes; ALEd - diameter of anterior lateral eyes; AMEd - diameter of anterior median eyes; PLEd diameter of posterior lateral eyes; PMEd - diameter of posterior median eyes; Ta - tarsus; $\mathrm{Me}$ - metatarsus, $\mathrm{Ti}$ - tibia; $\mathrm{Pa}$ - patella; $\mathrm{Fe}$ - femur; $\mathrm{Tr}-$ trochanter; $\mathrm{C}-$ coxa.

\section{Taxonomy}

\section{Genus Orthobula Simon, 1897}

Orthobula Simon, 1897: 152, type species $O$. impressa Simon, 1897.

Orthobula charitonovi (Mikhailov, 1986)

Figs 1-7, 11-23.

Trachelas c. Mikhailov, 1986: 799, f. 1a-ж (○’ㅇ).

O. c.: Mikhailov \& Fet, 1994: 511 (T from Trachelas)

O. c.: Danıșman et al., 2012: 1098, f. 1-5 ( $\sigma^{7}$ t)

MATERIAL EXAMINED. TURKEY: 1 O (AUZM), [T-02] Ankara Province, Hwy between Kizllcahamam-Ankara (40 21.133'N; 3240.811'E), 1000 m, 27.05.2009 (Y.M. Marusik); 2 우 (ZMMU), [T-08] Kayseri Province, Sultan Sazlığ1 National Park $\left(38^{\circ} 14^{\prime} 34^{\prime \prime} \mathrm{N}\right.$; $\left.35^{\circ} 11^{\prime} 52^{\prime \prime} \mathrm{E}\right) 815 \mathrm{~m}$, mainly under Tamarix

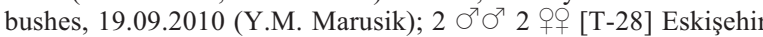

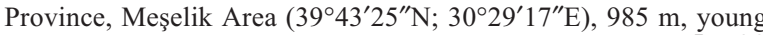
pine stand with oak shrubs, 26.09.2010 (Y.M. Marusik); $1 \sigma^{\prime \prime} 3$

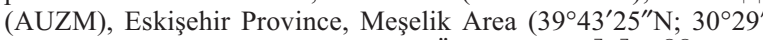
$17^{\prime \prime}$ E) 985 m, 26.09-2.11.2010 (R.S. Özkütük); $3 \sigma^{7} \sigma^{7} 4$ 우 5 juv. (AUZM), Ordu Province, Yarașlı Village $\left(40^{\circ} 58^{\prime} 39.26^{\prime \prime} \mathrm{N} ; 37^{\circ} 49^{\prime}\right.$ 45.37"E), 228 m, 7.11.2010 (R.S. Özkütük); 2 +o (AUZM), Antalya Province, Alanya District, Dim Valley $\left(36^{\circ} 32^{\prime} 28.00^{\prime \prime} \mathrm{N}\right.$; $32^{\circ} 5^{\prime}$ 49.00"E) 44 m, 13.12.2010 (K.B. Kunt); Ankara Province, Yenimahalle District, Türkkonut, Dodurga Village $\left(40^{\circ} 0^{\prime} 26.01^{\prime \prime N}\right.$; $32^{\circ} 35^{\prime} 23.78^{\prime \prime} \mathrm{E}$ ), $970 \mathrm{~m}, 28.06 .2011$ (K.B. Kunt); 1 ㅇ (AUZM) Adana Province, Pozantý District, Yeni Gökbez Village $\left(37^{\circ} 26^{\prime}\right.$ $34.08^{\prime \prime} \mathrm{N}$; 34 $\left.52^{\circ} 8.08^{\prime \prime} \mathrm{E}\right), 3.07 .2012$ (R.S. Özkütük); $1 \sigma^{\prime} 3$ +中 (AUZM), Ardahan Province, Çıldır District, Kakaç Village $\left(41^{\circ} 5^{\prime}\right.$ 22.25"N; 4320'23.63"E), 2189 m, 24.08.2012 (R.S. Özkütük). ISRAEL: 8 우 (ZMMU), [IL-01] Ramat-Aviv, botanical gardens, $32^{\circ} 06^{\prime} \mathrm{N} 34^{\circ} 48^{\prime} \mathrm{E}, 40 \mathrm{~m}, 26.12 .2010$ (Y.M. Marusik); 3 우 (ZMMU), [IL-02] Shuni Park, $1 \mathrm{~km} \mathrm{~N}$ Binyamina, 32 $32^{\prime} \mathrm{N} 34^{\circ} 57^{\prime} \mathrm{E}, 60 \mathrm{~m}$, 27.12.2010 (Y.M. Marusik); 64 90 (ZMMU), [IL-04] Ramat-Aviv, botanical gardens, $32^{\circ} 07^{\prime} \mathrm{N} 34^{\circ} 48^{\prime} \mathrm{E}, 40 \mathrm{~m}, 28.12 .2010$ (Y.M. Marusik); 4 우 [IL-05-06] Haifa, University campus and city garden, $32^{\circ} 45^{\prime} \mathrm{N} 35^{\circ} 01^{\prime} \mathrm{E}, 450 \mathrm{~m}, 29.12 .2010$, (Y.M. Marusik); 6 오 (ZMMU), [IL-08] Jerusalem University botanical garden, $35^{\circ} 12^{\prime} \mathrm{N}$ $31^{\circ} 46^{\prime} \mathrm{E}, 3.01 .2011$ (Y.M. Marusik); 13 우 (ZMMU), [IL-12] Judean Hills, $1 \mathrm{~km}$ E Beit Shemesh, $31^{\circ} 44^{\prime} \mathrm{N} 35^{\circ} 00^{\prime} \mathrm{E}, 230 \mathrm{~m}$, 6.01.2011 (Y.M. Marusik); 4 우 [IL-13] Judean Hills, 7 km NNE Beit Guvrin, $31^{\circ} 40^{\prime} \mathrm{N} 34^{\circ} 56^{\prime} \mathrm{E}, 300$ m, 7.01.2011 (Y.M. Marusik). GEORGIA: $2 \sigma^{7} \sigma^{7} 5$ juv. (ZMMU), Tbilisi, near TV tower, litter, sifting, steep slope, $41^{\circ} 41^{\prime} 52.5^{\prime \prime} \mathrm{N}, 44^{\circ} 47^{\prime} 05.2^{\prime \prime} \mathrm{E}, 528 \mathrm{~m}, 25.07 .2012$ (Y.M. Marusik). AZERBAIJAN: 3 O+ (ZMMU), [Az-16] CE Azerbaijan, ca $75 \mathrm{~km} \mathrm{~N}$ of Baku, W of Kylyazi Village, $40^{\circ} 51.5^{\prime} \mathrm{N}$ $49^{\circ} 11.5^{\prime} \mathrm{E}, 260 \mathrm{~m}$, semi-desert and relic poplar stand, 7.06.2003 (Y.M. Marusik). IRAN: $1 \sigma^{7} 3$ OO (ZMMU), [07] Fars Province, 40 $\mathrm{km} \mathrm{NE}$ of Shiraz, ca $2 \mathrm{~km} \mathrm{E}$ of Band-e-Amir Village, $52^{\circ} 47^{\prime} \mathrm{E}$ $29^{\circ} 52^{\prime}$ N, 25.05.2000 (Y.M. Marusik); 1 o $^{7} 3$ 우 (ZMMU), [09] Fars Province, Shiraz, $52.533^{\circ} \mathrm{E}, 29.607^{\circ} \mathrm{N}, 18-26.05 .2000$ (Y.M. Marusik); 4 우 (ZMMU), [15] Tehran Province, Plant-ProtectionOrganization Park, 51.414 ${ }^{\circ} \mathrm{E} 35.673^{\circ} \mathrm{N}, 7-22.06 .2000$ (Y.M. Marusik); 3 우 (ZMMU), [23] Tehran Province, NW of Tehran, Sardor Area, $10 \mathrm{~km} \mathrm{~N}$ of Karaj, $51^{\circ} 05^{\prime} \mathrm{E} 35^{\circ} 50^{\prime} \mathrm{N}, 13.06 .2000$ (Y.M. Marusik). UZBEKISTAN: 2 우 (ZMMU), Kuraminski Mt. Range, Kamchik-sai Gorge, 10.04.1985 (S.V. Ovtchinnikov).

DIAGNOSIS. Orthobula charitonovi differs from the similar O. crucifera by lacking a femoral apophysis, and by having a longer femur in the male palp (femur/cymbium ratio in $O$. charitonovi -0.75 and in O. crucifera - 0.5); females have oval and not elongated receptacles and widely spaced copulatory openings (span is as wide as in receptacles, span of copulatory openings 1.5 times less than that of the receptacles) and diverging insemination ducts (parallel in $O$. crucifera).

DESCRIPTION. Male: AL 0.73, CL 0.76, CWmax 0.53, CWmin 0.28, ALEd 0.04, AMEd 0.02, PLEd 0.05, PMEd 0.03. Female: AL 0.98, CL 0.81 Cwmax 0.63, Cwmin 0.37, ALEd 0.05, AMEd 0.03, PLEd 0.05 , PMEd 0.04 . 


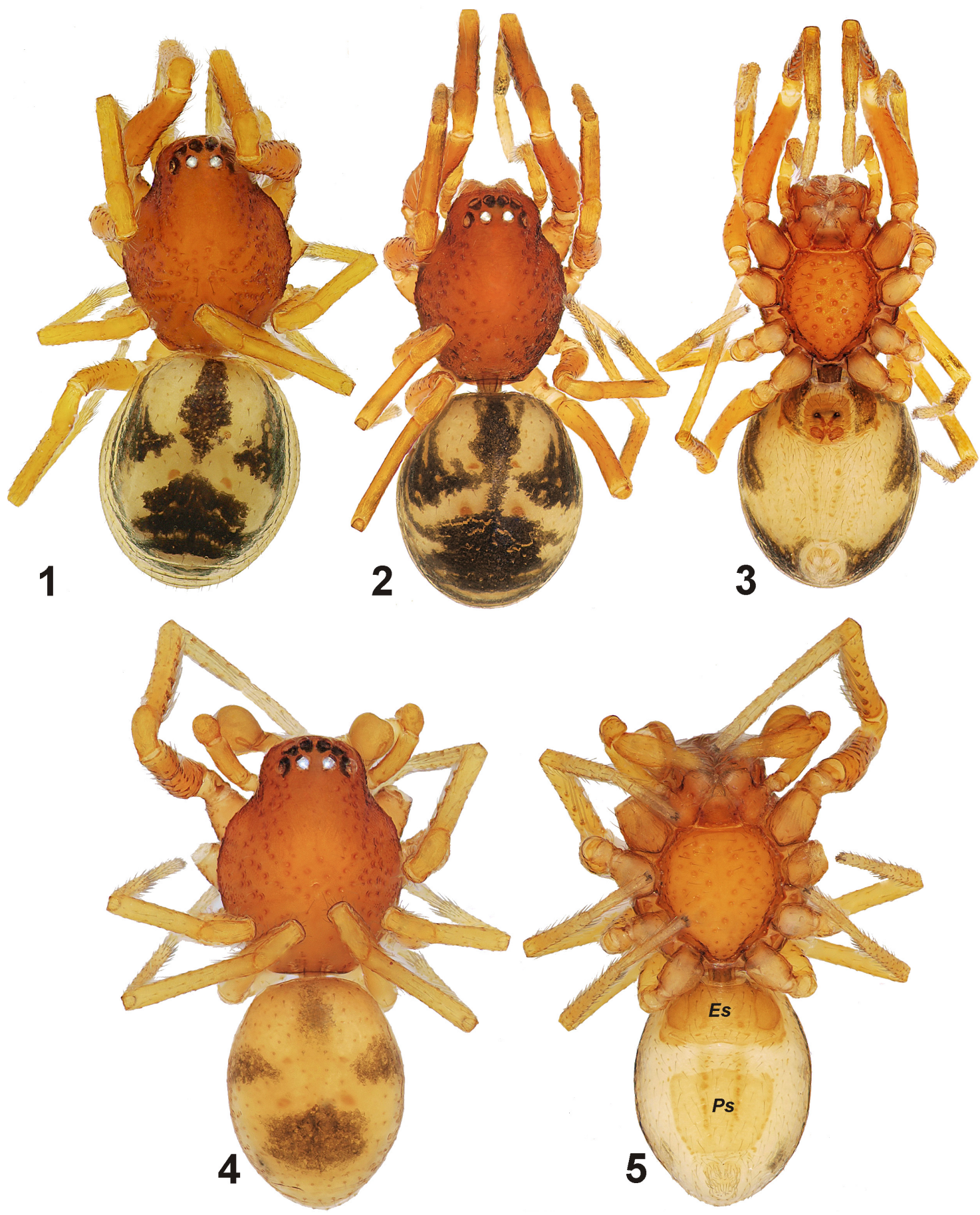

Figs 1-5. Habitus of Orthobula charitonovi from Turkey: 1-2 - female, dorsal view; 3 - female, ventral view; $4-$ male, dorsal view; 5 - male, ventral view. Abbreviations: Es - epigastral scutum, $V s-$ postepigastral scutum.

Рис. 1-5. Внешний вид Orthobula charitonovi из Турции: 1-2 - самка, сверху; 3 - самка, снизу; 4 - самец, сверху; 5 самец, снизу. Сокращения: $E s$ - эпигастральный скутум, $V s$ - постэпигастральный скутум.

Carapace, sternum, labium, gnathocoxae from light brown to orange, relatively darker in females. Carapace with numerous pits along the edges, becoming fewer in number towards the top. Anterior and posterior eye rows recurved. Lateral eyes two times bigger than median eyes in both rows. However, PME slightly bigger than AME. Fovea absent. Sternum with dark brown margins and evenly distributed pits. Intercoxal sclerite triangular. Dorsum of abdomen in males from pale yellowish to pale brown with scutum and distinct pattern composed of four spots. Females with more developed pattern: dark heart mark, lateral spots in 

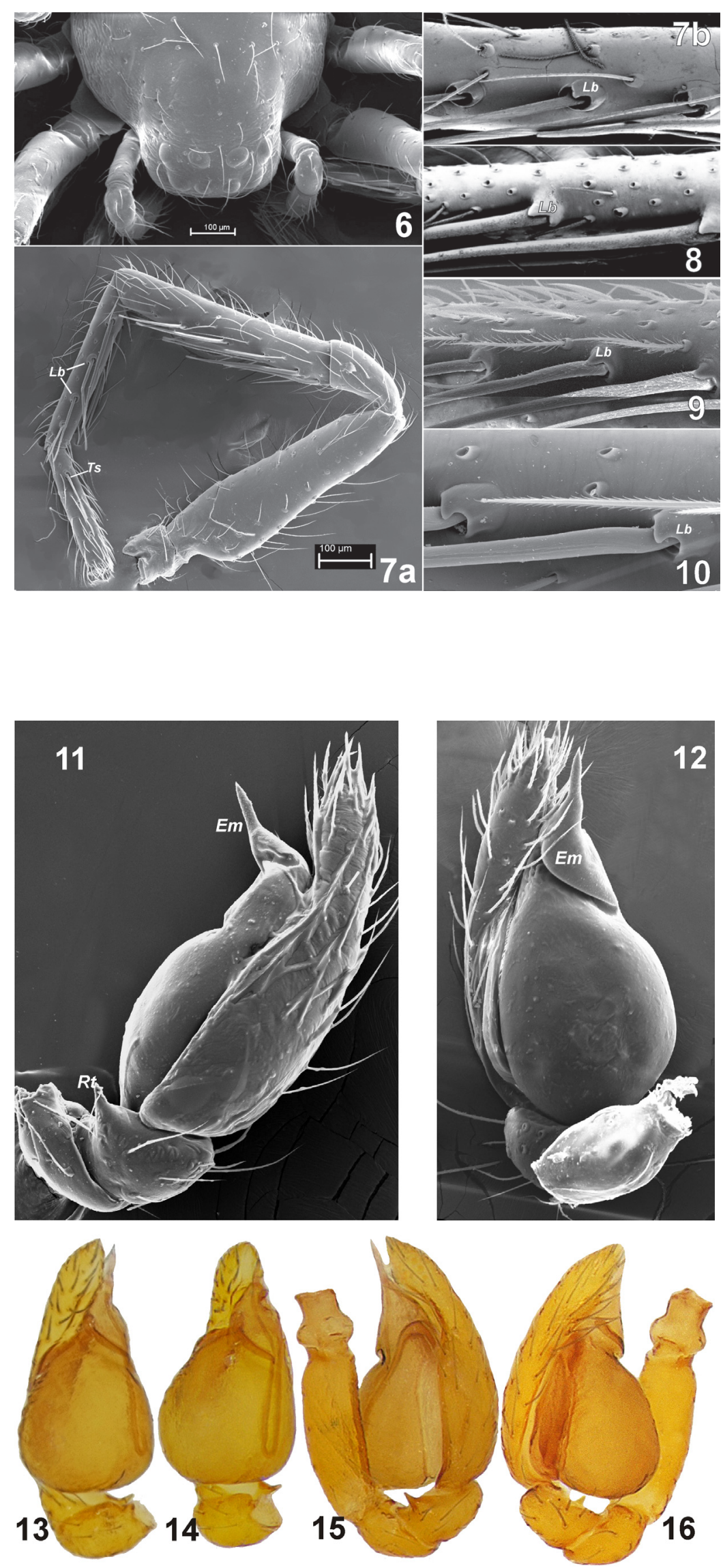

Figs 6-10. Orthobula charitonovi (6-7) and locking mechanism in different spiders (8-10) : 6 - juvenile female, showing eyes arrangement; $7 \mathrm{a}$ - leg I showing spination; $7 \mathrm{~b}$ - locking mechanism; $9-$ same, in Zora sp. from Turkey; 12 - same, in Phrurolithus festivus, Finland; 10 - same, in Oonops demesticus (Sochi, Russia). Abbreviations: $L b$ - base of spine with locking mechanism; Ts - tarsal spine.

Рис. 6-10. Orthobula charitonovi (6-7) и замковый механизм у разных пауков (810) : 6 - ювенильная самка, показано расположение глаз; 7a - нога I, показано вооружение; 7b - замковый механизм; 9 - замковый механизм, Zora sp. из Турции; 12 - замковый механизм, Phrurolithus festivus, из Финляндии; 10 - замковый механизм, Oonops demesticus (Сочи). Сокращения: $L b$ - основание шипа с замковым механизмом; $T s$ - шип лапки.
Figs 11-16. Male palp of Orthobula charitonovi: 11,15 - retrolateral view; 12 14 - ventral view; 16 - prolateral view. Abbreviations: Em - embolus, Rt - retrolateral tibial apophysis.

Рис. 11-16. Пальпа самца Orthobula charitonovi: 11, 15 - ретролатерально; 12-14 - снизу; 16 - пролатерально. Сокращения: $E m$ - эмболюс, $R t$ - ретролатеральный отросток голени. 

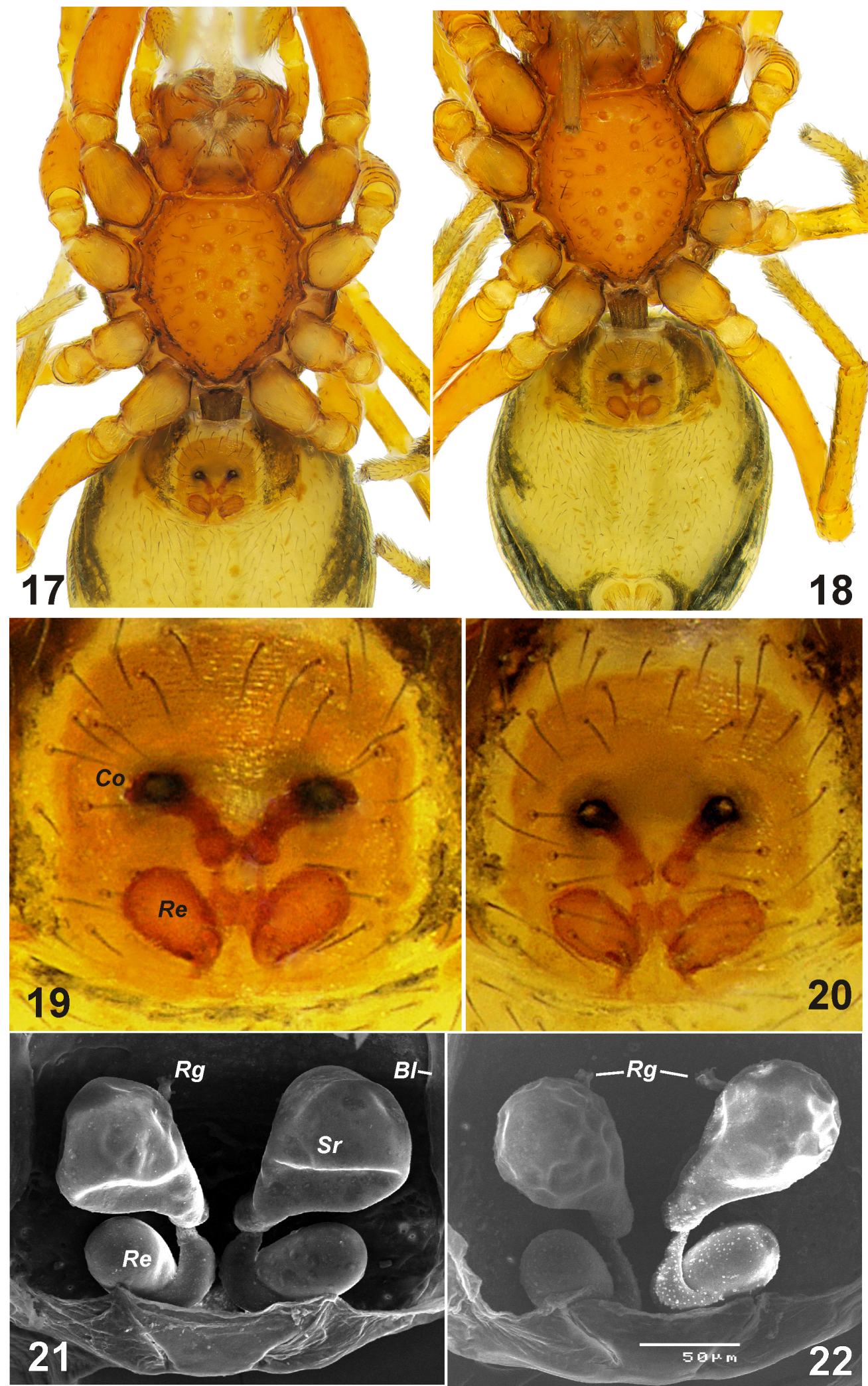

Figs 17-22. Female of Orthobula charitonovi: 14-15 - ventral view; 16-17 - epigyne, ventral view; 21-22 - epigyne, dorsal view. Abbreviations: $\mathrm{Bl}$ - book lung, $\mathrm{Co}$ - copulatory opening, $\mathrm{Re}$ - primary receptacle, $\mathrm{Rg}$ - receptacular gland, $\mathrm{Sr}$ - secondary receptacle,

Рис. 17-22. Самка Orthobula charitonovi: 14-15 - снизу; 16-17 - эпигина, снизу; 21-22 - эпигина, сверху. Сокращения: $\mathrm{Bl}$ - лёгкое, $\mathrm{Co}$ - совокупительное отверстие, $R e$ - основная рецептакула, $R g$ - железа рецептакулы, $S r$ — дополнительная рецетакула. 
Table 1. Leg measurements of Orthobula charitonovi ( $\left.\sigma^{\top} / P\right)$.

Таблица 1. Промеры ног Orthobula charitonovi ( $\left.\bigcirc^{7} / 9\right)$.

\begin{tabular}{|c|c|c|c|c|c|c|c|}
\hline Legs & $\mathrm{C}$ & $\mathrm{Tr}$ & $\mathrm{Fe}$ & $\mathrm{Pa}$ & $\mathrm{Ti}$ & $\mathrm{Me}$ & $\mathrm{Ta}$ \\
\hline I & $0.14 / 0.21$ & $0.08 / 0.11$ & $0.48 / 0.56$ & $0.18 / 0.19$ & $0.42 / 0.51$ & $0.31 / 0.35$ & $0.23 / 0.24$ \\
\hline II & $0.13 / 0.19$ & $0.07 / 0.09$ & $0.42 / 0.45$ & $0.16 / 0.18$ & $0.34 / 0.39$ & $0.29 / 0.38$ & $0.20 / 0.23$ \\
\hline III & $0.12 / 0.14$ & $0.07 / 0.08$ & $0.39 / 0.43$ & $0.16 / 0.17$ & $0.28 / 0.35$ & $0.31 / 0.33$ & $0.18 / 0.19$ \\
\hline IV & $0.18 / 0.21$ & $0.11 / 0.12$ & $0.43 / 0.59$ & $0.18 / 0.20$ & $0.35 / 0.54$ & $0.44 / 0.47$ & $0.26 / 0.29$ \\
\hline
\end{tabular}

anterior half and wide median band in posterior half. Venter of abdomen without pattern; males with epigastric $(E S)$ and postepigastric $(P S)$ scuta; females without ventral scuta. Legs orange-brownish in both sexes. Legs I and II with ventral spines on tibiae-tarsi, spination is shown in Table 2. Bases of spines with locking mechanism $(L b)$ (Fig. 7). Leg measurements are given in Table 1. Leg spination:

\begin{tabular}{|c|c|c|c|c|}
\hline$\sigma^{7}$ & Leg I & Leg II & Leg III & Leg IV \\
\hline $\mathrm{Ti}$ & $4 \mathrm{pv}-4 \mathrm{rv}$ & $5 \mathrm{pv}-4 \mathrm{rv}$ & 0 & 0 \\
\hline $\mathrm{Me}$ & $4 \mathrm{pv}-4 \mathrm{rv}$ & $3 \mathrm{pv}-4 \mathrm{rv}$ & 0 & 0 \\
\hline $\mathrm{Ta}$ & $3 \mathrm{pv}-3 \mathrm{rv}$ & $2 \mathrm{pv}-2 \mathrm{rv}$ & 0 & 0 \\
\hline $\mathrm{T}$ & \multicolumn{5}{|l|}{} \\
\hline $\mathrm{Ti}$ & $6 \mathrm{pv}-5 \mathrm{rv}$ & $5 \mathrm{pv}-4 \mathrm{rv}$ & 0 & 0 \\
\hline $\mathrm{Me}$ & $4 \mathrm{pv}-4 \mathrm{rv}$ & $4 \mathrm{pv}-4 \mathrm{rv}$ & 0 & 0 \\
\hline $\mathrm{Ta}$ & $3 \mathrm{pv}-3 \mathrm{rv}$ & $2 \mathrm{pv}-2 \mathrm{rv}$ & 0 & 0 \\
\hline
\end{tabular}

Male palp as in Figs 11-16, femur long, without apophysis; patella unmodified; tibia wider than tall, with small conical, ventrally directed retrolateral apophysis $(R t)$; cymbium long, longer than femur; bulbus as wide as long (not including embolus); embolus $(E m)$ massive, thorn-like.

Epigyne as in Figs 19-22, with clearly visible eggshaped receptacles $(R e)$, diverging insemination ducts and copulatory openings; insemination duct with round shaped thickening resembling receptacles, lateral edges of copulatory openings $(\mathrm{Co})$ spaced like lateral edges of receptacles. Vulva with two pairs of receptacles, egg shaped primary receptacles and weakly sclerotized secondary receptacles $(\mathrm{Sr})$ (or these structures can be called as sacks) which seem connected with copulatory openings. Secondary receptacles with glands $(R g)$.

DISTRIBUTION. This species is distributed from western Anatolia to Kyrgyzstan and from Israel to Tajikistan and is found in the following countries: Armenia, Azerbaijan, Georgia, Iran, Israel, Kyrgyzstan, Turkey and Turkmenistan [Mikhailov, 1997 and present data]. The occurrence of this species in Syria, Lebanon, Jordan, Pakistan and Afghanistan is very likely.

NATURAL HISTORY. Orthobula charitonovi occurs in semixeric habitats from sea level to almost $2000 \mathrm{~m}$ altitude in the mountains. It is active in almost all seasons in regions dominated by the typical Mediterranean climate. Although approximately 100 specimens were collected in Israel in late December, males were absent at the beginning of January. Maybe they occur in spring - autumn and are absent in winter.

DISCUSSION. Given the large numbers of specimens from very distant localities we expected to find certain differences in size, pattern, or structure of the copulatory organs. However, detailed comparisons revealed no differences.

Although we found locking mechanism in Orthobula for the first time, it seems that such mechanism exists in many unrelated groups. For example we found similar mechanism in Phrurolithus festivus (C.L. Koch, 1835) (Fig. 9), Zora sp. (Fig. 10). It is also known in Phrurotimpus Chamberlin et Ivie, 1935, Drassinella Banks, 1904 (Corinnidae), Hesperocranum Ubick et Platnick, 1991 (Liocranidae) (Bosselaers, pers. communication), or unrelated Oonopidae (cf. Fig. 10).

ACKNOWLEDGEMENTS. We thank Sergei Zonstein (Tel Aviv) for the help in collecting material in Israel, Kirill G. Mikhailov (Moscow) for allowing to study unidentified material from ZMMU. We are also obliged to Mykola M. Kovblyuk (Simferopol, Ukraine) and Jan Bosselaers (Beerse, Belgium) for reviewing manuscript. David Penney (Manchester, UK) is thanked for his kind help in editing the English. This study was supported in part by the Russian Foundation for Basic Research (grants \#\# 11-0401716 and 12-04-01548) and Anadolu University Scientific Research Projects Commission under the grant no: 1001F31.

\section{References}

Danışman T., Erdek M., Sancak Z., Coşar İ. 2012. A new genus record for the corinnid sac spider fauna of Turkey (Araneae: Corinnidae) // Munis Entomology \& Zoology. Vol.7. No.2. P.1097-1100

Bosselaers J., Jocqué R. 2002. Studies in Corinnidae: cladistic analysis of 38 corinnid and liocranid genera, and transfer of Phrurolithinae // Zool. Scripta. Vol.31. P.241-270.

Kamura T. 2009. Trochanteriidae, Gnaphosidae, Prodidomidae, Corinnidae // Ono H. (ed.). The spiders of Japan with keys to the families and genera and illustrations of the species. Kanagawa: Tokai Univ. Press. P.551-557.

Mikhailov K.G. 1986. New species of spiders from the families Clubionidae and Liocranidae from the middle Asia and the Caucasus // Zoologicheski Zhurnal. Vol.65. No.5. P.798-802 [in Russian].

Mikhailov K.G., Fet V. 1994. Fauna and zoogeography of spiders (Aranei) of Turkmenistan // Fet V. \& Atamuradov K. (eds.). Biogeography and Ecology of Turkmenistan. Monogr. Biol. Vol.72. Dordrecht etc.: Kluwer Academic Publ. P.499-524.

Otto S., Tramp S. 2011. Caucasian Spiders. A faunistic database on the spiders of the Caucasus, Version 2.0. Online at http:// caucasus-spiders.info (accessed May 24, 2012).

Platnick N.I. 2013. The World Spider Catalog, Version 13.5 American Museum of Natural History, online at http://research. amnh.org/entomology/spiders/catalog/index.html

Simon E. 1897. Etudes arachnologiques. 27e Mémoire. XLII. Descriptions d'espèces nouvelles de l'ordre des Araneae // Ann. Soc. ent. Fr. T.65. S.465-510.

Responsible editor K.G. Mikhailov 